Forfattere:

Liss Eriksen, Høgskolelektor ved Høgskolen i Finnmark, Institutt for helsefag

Adresse: Radarveien 14, 9600 Hammerfest

Telefon dagtid: 95902360

e- postadresse: liss.eriksen@hifm.no

Jeanette Huemer, Høgskolelektor ved Høgskolen i Finnmark, Institutt for helsefag

Adresse: Skjåholmen, 9620 Kvalsund

Telefon dagtid: 97749994

e-postadresse: jeanette.huemer@hifm.no

\title{
Dialogkonferanse i klasserommet - bro til bedre læring
}

\section{Ingress}

Ideelt skal et studium innen praktiske fag føre til et «kick» når man er ferdig og står i den praktiske virksomheten studiet kvalifiserer for. Overgangen mellom profesjonsstudier og praksis har imidlertid generelt vist seg å være en akilleshæl. Artikkelen er en beskrivelse og en diskusjon av et fornyende studentaktivt pedagogisk prosjekt, som et alternativ til tradisjonell klasseromsundervisning. Her diskuteres erfaringer med bruk av dialogkonferanse og Appreciative Inquiry som del av en aksjonslæringsprosess for studenter i sykepleierutdanningen. Målet er å vise et pedagogisk verktøy som kan bidra til å bygge en sterkere bro mellom teori og praksis i klasseromsundervisning.

\section{Praksiskick eller praksissjokk?}

Sykepleierutdanningen er en treårig bachelorutdanning. Sykepleie er et praktisk fag som består av ulike kunnskapskomponenter. Integrasjon av teori og praksis er avgjørende for utøvelsen av faget. Den teoretiske delen av studiet er lagt til høgskolen. Halvparten av studiet er praktiske studier. 
Samfunnets behov for sykepleiere i alle deler av helsetjenesten krever variert grad av spesialisering innen disiplinens fagområder. Lov om universiteter og høgskoler har eksplisitte krav om at utdanningens ferdige kandidater skal være kvalifisert til å delta kontinuerlig $\mathrm{i}$ fornying av sine respektive yrkesfelt (Kunnskapsdepartementet 2005). Rammeplanen for 2008 har fokus på endringsorientering og evne til «å lære å lære», med begrunnelse i et stadig mer komplekst arbeidsliv og stor stofftrengsel i alle de fagområder som sykepleieren må mestre (Kunnskapsdepartementet 2008). Også helsevesenets nye utfordring, samhandlingsreformen, krever store endringer i kompetansen til sykepleierne, og tilgjengelige ressurser må i framtida benyttes annerledes enn i dag (St.meld. 47 2008). Sentrale myndigheter har $\emptyset \mathrm{kt}$ fokus på betydningen av høy kompetanse innen organisasjon og ledelse og evne til endringsorientering (St.meld. 28 1999). Dette berører oss som utdanningsinstitusjon. Vi må også endre vår tenkning og flytte oppmerksomheten fra undervisning til læring (St.meld. 47 2008-2009).

Sykepleiere har ledelse og koordineringsfunksjoner i sin profesjon. Som faglærere ved Høgskolen i Finnmark, med tidligere erfaring som ledere både fra kommune- og spesialisthelsetjenesten, fikk vi ansvaret for ledelsesundervisningen fra 1998. Undervisningsformen var tradisjonell forelesning, og etter første året hadde vi erfart at det var dårlig oppmøte, med studenter som uttrykte at undervisningen var kjedelig og lite relevant for praksis. Pensumlitteraturen hadde fokus på teorier som hadde liten praktisk tilnærming. Vi ble derfor enige om å endre undervisningsopplegget, og vurderte ulike pedagogiske strategier for å få til en mer aktiv læring for studentene. En læring som kunne øke deres kompetanse til et komplekst arbeidsliv etter fullført studium.

Overgangen fra sykepleierstudent til yrkesaktiv sykepleier er av flere forskere beskrevet som problematisk. Det pekes blant annet på relevansproblemer samt parathet og forberedelse til det arbeidspress og ansvar de nyutdannede sykepleierne får (Havn \& Vedi 1997; Kirke-, utdannings- og forskningsdepartementet 1999; Espeland \& Indrehus 2003). For læreryrket ble begrepet «praksissjokk» diskutert heftig på 70- og 80-tallet (Jordell 1986), og har i flere tiår vært en samlebetegnelse for overgangsproblemene. Alvsvåg og Førland (2004) er blant dem som har diskutert problemene på overgangsbroen mellom studietilværelse og aktivt yrkesliv. De hevder at høgskolene har utfordringer knyttet til både å synliggjøre og legitimere de teoretiske fagenes relevans for yrkesutøvelsen, og at sykepleielærerne står i en kryssild mellom studentenes forventninger om praksisnære lærere og myndighetenes vektlegging av akademisk kompetanse. Mange nyutdannede sykepleiere opplever et kompetansegap mellom 
utdanningen og kravene i arbeidslivet (Smeby \& Vågan 2007). Dette blir beskrevet som et praksis-, realitets- eller virkelighetssjokk (Stronach mfl. 2002; Maben, Latter \& Clark 2006) og forstås som et gap mellom hva utdanningen kan tilby og det arbeidslivet etterspør. Målet må være å fjerne «sjokket» og stimulere til et «praksiskick», på en slik måte at starten i yrket byr på gjenkjenning fra studietida som kan gi faglig trygghet og stimulans. Vi har valgt «broen» som metafor for de pedagogiske verktøy vi velger for at studentene skal kunne krysse gapet fra studier til arbeidsliv.

Orvik (2002) trekker fram flere undersøkelser som viser at nyutdannede sykepleiere savner verktøy som gjør dem i stand til å forbedre pasientomsorgen og endre egne arbeidsbetingelser. For samfunnet er det viktig at sykepleierstudiet gjør studentene i stand til å være kritisk til og ha mot til å være grenseoverskridende for å forbedre praksis. I denne artikkelen rettes søkelyset mot nye arbeidsmåter og læringsformer, og vår problemstilling ble derfor: Hvordan kan dialogkonferanse i klasserommet som pedagogisk verktøy være med på å bygge en sterkere bro mellom teori og praksis?

\section{Valg av pedagogisk tilnærming}

Å lede læringsprosesser handler om å få den enkelte og gruppen til å overskride grenser innenfor trygge rammer. En slik ledet grenseoverskridelse muliggjør utveksling, samhandling, ny kunnskap og innsikt (Brunstad 2009). I undervisningen i ledelse er målet at studentene skal få oppleve å overskride grenser innenfor trygge rammer.

Valget falt da på aksjonslæring som pedagogisk tilnærming på grunn av dens prinsipper om nærhet, dialog og aktiv deltakelse. Aksjonslæring er på mange måter praktikerens variant av aksjonsforskning. Tiller (2006) sier at aksjonslæring er aksjonsforskningens «lillesøster»og har mye til felles med erfaringslæring. Forskjellen mellom aksjonslæring og erfaringslæring er imidlertid at mens erfaringslæring er tilbakeskuende, så er aksjonslæring rettet framover og orientert mot grenseoverskridelse.

Aksjonslæring er en form for kunnskapsinnhenting fra praksis, slik at en på en systematisk måte kan trekke erfaringer ut av det som skjer og bygge på disse i den videre planleggingen. Tiller (2004) sier at nytteverdien for deltakerne kommer fram ved den bevisstheten som skapes og den systematiske refleksjonen gjennom arbeidsprosesser. Formålet er å utforske praksisfeltet slik at bevisstheten og forståelsen $\varnothing \mathrm{kes}$, igangsette målrettede utviklingsprosesser både i organisasjon, grupper og hos den enkelte, og publisere utført arbeid, slik at det kan 
brukes som inspirasjon til refleksjon og handling for andre. Han sier også at ideelt sett bør rapporten oppleves av deltakerne som en sann framstilling av forløp og resultat (Tiller 2004).

Ifølge Tiller (2006) er en viktig hovedforskjell mellom aksjonslæring og aksjonsforskning at deltakerne i aksjonslæringen ikke er forskere, selv om de likevel forholder seg forskende til sitt arbeid og sin hverdag. En annen forskjell er de grundige forskningskrav som stilles til rapportering, og som krever forskningskompetanse gjennom systematisk opplæring. De samme krav er ikke til stede i like stor grad i aksjonslæring (Tiller 2006). Det viktige i vår sammenheng er likevel relasjonen mellom forskeren og forskende praktikere; det som Tiller (2006) beskriver som forskende partnerskap.

Aksjonsforskning har vært mest brukt innen humanistiske profesjoner hvor det arbeides med prosesser hvor sosiale relasjoner er viktige. Det finnes mange definisjoner, og felles for alle er at aksjonsforskning innebærer forbedring av praksis gjennom refleksjon over handling (Løchen 1973; Kalleberg 1992).

Aksjonsforskningens fokus på endring eller forbedring av praksis innen et sosialt fellesskap, fordrer at forskeren selv er aktiv i å gripe inn i feltet som studeres. Denne forbedringsprosessen blir også en del av selve forskningsprosessen. I aksjonsforskningen møtes forskere og praktikere i dialog for sammen å ta et tak i en ønsket utviklingsprosess. Dialogen mellom forsker og praktiker er en nøkkelfaktor i aksjonsforskningen. Praktikerne skal ha eierforhold til både kunnskapsproduksjon og praksisforbedring. Forskerne skal ikke primært forske på praktikerne, men med dem. Idealet er et forskende partnerskap (Tiller 2004, 2006).

Det pedagogiske verktøyet vi valgte å prøve ut var dialogkonferanse (Adizes 1991; Gustavsen 1996; Pålshaugen 2002). De tema som ble i fokus i undervisningen var: endringsledelse, konflikthåndtering med arbeidsmiljøkartlegging og introduksjon til aksjonsforskning (Eriksen 2007). Ifølge Gustavsen (1996) er begrepet «dialogkonferanse» utviklet i forbindelse med aksjonsforskning i arbeidslivsorganisasjonene på 1980-tallet. Konferanse kommer av begrepet «confer» og betyr å bringe sammen, sammenkomst og rådslagning. Dialogen forutsetter minst to parter som er opptatt av å føre en samtale. Gustavsen (1996) sier videre at dialogkonferanser er utviklet som et redskap for kunnskapsutvikling gjennom samtaler mellom involverte parter som møtes. 
Reason og Bradbury (2001) beskriver over 30 ulike måter å lede slike prosesser på. En måte er med positiv spørsmålsstilling: Appreciative Inquiry. Begrepet er ikke oversatt til noe nordisk språk, men «appreciative» betyr takknemlig eller anerkjennende. Dette kan gjenkjennes i Skrøvset og Tiller (2011) som har brukt betegnelsen «verdsettende», og snakker her om det verdsettende lederskapet. «Inquiry» oversettes med forespørsel, unders $\varnothing$ kelse eller etterforskning (Lingua 1996). Appreciative Inquiry er utviklet som en gren innenfor aksjonsforskning, og er blitt en tilnærmingsmåte og et verktøy for organisasjonsutvikling.

Knowles (1970) vektlegger at voksne lærer best ved å knytte ny kunnskap til sin omfattende erfaringsbakgrunn slik at den gir mening. Jacobsen (2001) definerer erfaring som handling, og i begrepet erfaring ligger at vi som mennesker opplever at handlingen berører oss følelsesmessig og skaper en forståelse for det opplevde. I undervisning bør man la den lærende selv bidra med sin forståelse av og erfaring med temaet, i stedet for å forelese om det først.

«Det er helt afgørende at respektere livserfaringens egenværdi og sætte normer for, at deltagerne gør det» (Jacobsen 2001:43). Jacobsen mener at undervisningen blir interessant når den lærendes erfaring er utgangspunkt og fokus. Tiller (1998) kaller dette for det «didaktiske møtet».

De senere år har det vært økende fokus på at ledelse ikke bare er en instrumentell ferdighet, men også innbefatter emosjoner og verdier i møte med medarbeiderne. Brunstad (2009) sier at i alt lederskap er det en ikke uvesentlig forskjell på å gjøre ting riktig og å gjøre de riktige tingene. Dette kaller han klokskap. Klokskap er en viktig egenskap i alt lederskap, også for undervisningspersonell. Brunstad vektlegger kreativitet og spontantintet i lederskap; et lederskap som tør å være grensesprengende (Brunstad 2009). Antonsen (2009) er opptatt av individets motivasjon. Det å være en deltakende aktør fører til bevisstgjøring om sosiale og materielle strukturer, som skaper positive emosjoner som har betydning for arbeidsfellesskapet. Starrin (2009) er opptatt av emosjonenes betydning i læring, de har en signalfunksjon som gjør oss bevisste.

Vi har valgt å også ha fokus på lærernes læring, da vi er i en dialog med studentene og deltar i samme kollektive læringsprosess, noe Levin og Klev (2002) kaller den samskapte læringsmodellen. 


\section{Materiale og metoder}

Data til denne studien ble samlet inn fra 2004 til 2011 og baserer seg på artikkelforfatternes $\operatorname{logg}$ fra prosessen og anonyme skriftlige evalueringer fra 162 studenter fordelt på seks kull. Data er innhentet både individuelt og gruppevis, og studentene hadde gitt tillatelse til at data kunne benyttes. Evalueringene baserte seg på et åpent spørsmål: «Si noe om hvordan du/dere har opplevd disse to temadagene. Hva bør vi beholde og hva bør forbedres?»

I analysen av datamaterialet valgte vi en innholdsanalytisk tilnærming. Evaluering og logg ble gjennomgått av artikkelforfatterne hver for seg, og meningsbærende enheter markert (Patton 2002). Vi diskuterte det vi hadde funnet og utviklet sammen forslag til underkategorier og hovedkategorier (Ricœur 2001). Først kategoriserte vi i henhold til strukturen i dialogkonferansen og deretter i henhold til studentenes opplevelse av læring ut fra perspektiver som mening, nytte og deltakelse.

Etiske vurderinger er gjort underveis med hensyn til anonymisering av data. Studien er forankret $\mathrm{i}$ institusjonens ledelse og har vært til vurdering hos NSD/personvernombudet, som ikke anså den som melde- eller konsesjonspliktig etter Personopplysningslovens $§ § 31$ og 33 (Ruyter, Førde \& Solbakk 2007)

I aksjonslæringsprosessen var vi og studentene nære da vi hadde vært i en prosess sammen som likeverdige parter. Det berører utfordringer knyttet til nærhet og avstand mellom forsker og informant, det vil si vår posisjonerte innsikt. Dette har vi hatt bevissthet rundt både underveis og i utvelgelse av data. Noe av nærheten ble redusert ved at vi samlet data over flere år og fra mange studentgrupper (Paulgaard 1997).

Dialogkonferansen var ikke obligatorisk undervisning, noe som gjorde at opptil halvparten av enkelte klasser valgte å ikke delta. Slik sett er det muligens de mest motiverte studentene som har deltatt, noe som vil kunne påvirke resultatet av evalueringene.

Hovedfunnene var at studentene så umiddelbar praktisk nytte i bruk av dialogkonferanse som verktøy i en arbeidshverdag, og at de erfarte utvikling og læring gjennom prosessen. Funnene blir illustrert som sitater underveis i artikkelen. 


\section{Å gå sammen}

Undervisningen ble organisert som dialogkonferanse over to temadager, med arbeidsmiljøkartlegging av studentenes egen studiesituasjon som tema første dag, og etterlesing og teori knyttet til dialogkonferanse som verktøy samt aktuelle tema innen endringsledelse eller konfliktforebygging andre dag. Erfaringene fra dagen før ble anvendt som eksempler. Dialogkonferansen slik vi organiserte den, ble strukturert i en prosess over fire trinn, gjennomført med fra 15 opp til 65 studenter på hvert kull.

Tidsperspektivet for begge dagene var ca. seks timer avhengig av antall deltakere. Vi vil gå noe nærmere inn på prosessen og ta med noen av studentenes utsagn underveis.

\section{Informasjon og innledning}

Dagen startet med informasjon om kartlegging av arbeidsmiljø, at vi som lærere var prosjektledere og hadde satt opp følgende spilleregler: Det skal ikke være personangrep, det er lov å mene hva man vil, og man skal vise respekt for andres syn.

Brunstad (2009) viser til at det er svært viktig å få frem at alles meninger er likeverdige og legitime, fordi det kan danne grunnlag for og motivere til positive endringer av utfordringer i studiesituasjonen. Prinsippet er at den som berøres skal også ha rett til å bli hørt. Å trekke studenter med i utvikling av kvaliteten på studiet kan bidra til at det skapes en ny kraft, og de blir en ressurs i dette arbeidet (Tiller 1998). Samtidig var det en læringsprosess som de kunne dra nytte av senere. Studentene oppfattet dette som positivt: «Alle ble hørt og alt ble like viktig».

\section{Kartlegging av studentenes arbeidsmiljø}

Dialogkonferansen startet med en kartlegging av styrker og utfordringer. Vi var enige om å legge vekt på en positiv vinkling i utviklingsprosessen gjennom Appreciative Inquiry (Reason \& Bradbury 2001) og dette framkom i spørsmålsstillingen.

Vanskelige problemstillinger kan skape avstand, uttrykke maktforhold og dermed hindre at enkelte deltar emosjonelt. Starrin (2009) sier at interaksjoner som preges av makt og status tar 
emosjonell energi fra deltakerne. Formuleringen ble derfor enkel for ikke å fremmedgjøre. Studentene besvarte så følgende oppgave anonymt: «Kan dere skrive maks to positive og to negative ting om å være sykepleierstudent?»

Metodikken leter fram til og tar tak i motivasjonen og det som gir «læringsenergi» og hverdagskraft (empowerment) hos medarbeideren eller studenten. Den kobles med en overordnet prosjektledelse som vil, forplikter og bygger på verdsettingens grunn som illustreres med følgende studentutsagn: «Bra: har lært noe nytt i dag å $\odot$ Flott å fokusere på det positive også. Det er vel noe vi vet, men viktig å poengtere det - ser det godt i et slikt sammendrag/sammenheng».

De anonyme kommentarene som studentene leverte inn, ble skrevet på flipover-ark slik at alle kunne se dem. Anonymitet $\mathrm{i}$ innlevering av arkene med positive og negative synspunkter ga den enkelte trygghet til å si sin mening.

Alle ble utfordret underveis. Hele første del av prosessen hadde lite fokus på produkt og stort fokus på forståelse av «den andre». Samtidig var den «stramme» strukturen en forutsetning for å komme videre til en mer løsningsorientert del senere i prosessen (Jacobsen 2001).

\section{Opprydding og prioritering av kartleggingen}

De positive synspunktene ble satt opp i klasserommet i den hensikt å minne alle om det som var positivt. Deretter jobbet vi med utfordringene med å være student. Ved å bli bevisst på det positive ønsket vi å bidra til overskudd for utvikling (Reason \& Bradbury 2001). Av erfaring vet vi at om vi starter med barrierer, hindringer og flaskehalser så tappes kraft og energi, slik at endringene og de overskridende tiltakene kan stoppe tidlig i prosessen (Starrin 2009).

De negative stikkordene/utsagnene ble strukturert ved hjelp av studentene. Dermed ble de bedre kjent med hverandres synspunkter, samtidig som de også fikk et innblikk i og selv avgjorde hvilke utsagn som ble definert under hver hovedkategori. Studentene valgte selv hvilken av hovedkategoriene de ønsket å jobbe videre med, hvilket tema de skulle bidra under. Studentene ble dermed både involvert og deltakende i arbeidsformen, noe som bidro til en produktivitet, slik Pålshaugen (2002) påpeker som en sentral intensjon med dialogkonferanse. En hovedkategori som alltid fremkommer er fysisk arbeidsmiljø, men dette blir sjelden eller aldri prioritert av studentene. Arbeidsformen er dermed en bevisstgjøring på at ikke alt som er negativt vurderes som så viktig at det prioriteres å jobbe med. 


\section{Fra problembeskrivelse til løsningsorientert handling}

På denne tiden i prosessen har vi erfaring med at studentene er slitne eller at de «føler seg litt tomme». Momentene som kom opp måtte få modne litt og vi tok en lengre pause med lunsj/frukt før videre jobbing. En studentgruppe sier: «Fikk tenkt og fundert og spist god frukt!»

Gruppene jobbet så med valgt tema og framlegg for hverandre på slutten av dagen. For å komme inn i handlingsfasen var det viktig å diskutere løsninger og ikke beskrive utfordringene da de allerede var kjent. Studentene måtte være realistiske og fokusere på egen holdning og handling først, og deretter hva andre måtte gjøre.

Hensikten var å imøtekomme aksjonslæringens fokus på handling og løsning av egne utfordringer. Dialogkonferansen la vekt på respekt og at man brukte egne evner for å løse egne problemer. Dette skapte et utgangspunkt for videre utviklingsarbeid og la grunnlaget for dialog og samarbeid. Tilbakemeldinger fra deltakerne kan illustrere dette:

«Vi ble fokusert på å finne løsninger på problemene. Vi så også at for å forbedre kvaliteten, må også vi som studenter komme mer på banen.»

«Å snakke i grupper, synliggjøre problemstillinger for eksempel med tidsklemma var bra. Veldig lignende problemer hos alle.»

Gruppene utarbeidet handlingsplan ut fra stikkordene: Hva er utfordringen, hvilke tiltak kan være aktuelle, hvem skal iverksette tiltak og når bør arbeidet igangsettes? Vi strukturerte dokumentasjonen og tilbakeførte til studentene via nettportal.

Det ble presisert at det ikke skulle være diskusjon etter hvert framlegg, men kun innspill til hver gruppe. Studentene hadde allerede hadde valgt temaet de ønsket mest og fikk legitimitet for arbeidet gjennom dette.

Vi prioriterte tidsbruken til gruppenes arbeid. Pålshaugen (2002) sier at tidsbegrensning i plenum er viktig så det ikke tar tid fra deltakernes aktive diskusjoner i gruppene. Han anbefaler at om lag 2/3 av tiden brukes til deltakernes diskusjoner, refleksjoner og dokumentasjoner i gruppene. 
Studentene reflekterte skriftlig over hvordan de hadde opplevd den pedagogiske tilnærmingen med dialogkonferanse, aksjonslæring og Appreciative Inquiry. Følgende utsagn illustrerer et av hovedfunnene: «Var en liten oppvekker da vi så at de negative listene var mye vi kan gjøre med det selv. At vi har ansvar selv for å ta tingene videre. Flott at vi også måtte fokusere på det positive». Denne gruppa hadde jobbet med problemstillinger rundt internettilgang for studentene utenfor campus. I løpet av dialogkonferansen og gruppearbeidet fant de ut at dette var noe de måtte ta tak i sjøl, og presenterte ulike forslag til hva de kunne gjøre. Etter dialogkonferansen satte de i verk planene - og startet dermed en ny aksjon.

\section{Intensjoner møter realiteter}

Lærerrollen i dette prosjekt innebar både gjensidighet, ydmykhet og grenseoverskridelse. Gjensidighet handler om å få og gi. Didaktisk gjensidighet forutsetter likeverd og konsistens mellom verktøy som brukes og de målene en vil nå (Bjørndal \& Lieberg 1978). Vi som lærere måtte vise at vi mente det vi sa ved å være tro mot likeverdighetsprinsippene $\mathrm{i}$ aksjonslæring og dialogkonferanse. Gjennom ikke å kommentere eller diskutere de meningene som framkom underveis, søkte vi å vise ydmykhet for at den som berøres skal høres. Studentenes åpenhet forutsatte at vi ikke blandet oss inn og tolket deres utfordringer. Vi gikk ut av den ordinære lærerrollen som formidler, og inn i en rolle som innebar en grenseoverskridelse for oss, i den forstand at selv om vi hadde en tydelig plan og struktur for undervisningen, bestemte studentene innholdet. Som pedagoger måtte vi stå i det som kom der og da. Etzioni (1967) kaller denne typen planlegging for «mixed scanning». Dette innebærer både en planlegging hvor man forsøker å tenke seg fram til ulike scenarioer som kan oppstå i prosessen, samtidig som man tar høyde for håndtering av situasjonene som dukker opp underveis. Altså en planlegging som innbefatter både forberedthet og impulsivitet (Etzioni 1967).

Dialogseminar som arbeids/læringsform krever improvisering underveis for å ta tak det studentene uttrykker både verbalt og nonverbalt. Vi anvendte tolærersystem med bruk av «skygging» (shadowing) (Tiller 1986, 2006), for bedre å kunne se og ta tak i studentenes reaksjoner og lede dem videre i prosessen, men vi fikk også en konstruktiv tilbakemelding fra hverandre på egen lærerrolle. Studentene opplevde det slik: 
«Veldig positive lærere, som skapte et positivt miljø. Det var artig å se at lærerne hadde lagt vekt på noe av de samme problemstillingene som vi.»

«Det var også kjempe bra (og viktig) at lærerne er så engasjerte som de er.»

I utgangspunktet var ideen at dialogkonferanse med Appreciative Inquiry kunne være et godt læringsverkt $\varnothing y$ for å bidra til at studentene sto bedre rustet i møte med utfordringer som krever endringer. Som lærere måtte også vi være grenseoverskridende, det vil si stå i det ukjente sammen med studentene. Ifølge Brunstad (2009) er grenseoverskridelse en åpning for å handle sammen med studentene, en samhandling som kan bidra til ny kunnskap og innsikt. Hensikten i denne sammenhengen var å bidra til studentenes endrings- og samhandlingskompetanse, og at de opplevde å ha fått kunnskap og verktøy som kunne ha overføringsverdi til arbeidslivet.

Her synes vi å oppnå kontakt med målet, ut fra studentsynspunkt: «Veldig aktuelt tema i forhold til min jobb. Aksjonslæring er en prosess som får med seg alle - det er positivt. Positivt å lære om arbeidsformer som kan brukes i praksis».

\section{Mening, nytte, deltakelse}

Vår erfaring var at studentene ble svært engasjert under dialogkonferansen, det var få, om noen som meldte seg ut. De hadde ressurser til å finne egne løsninger på utfordringene når de metodiske rammene ga rom for det. Likeverdigheten praktisert på denne måten $\mathrm{i}$ klasserommet representerte et «brudd» med forelesningsmetoden og lærer/studentrollen. Brunstad (2009) påpeker at det å bryte med konvensjonelle rammer påkaller en ubalanse som gjør at man leter etter en ny sammenheng, eller ny mening. Vi mener at denne måten å møte studentene på ikke bare er opplæring, men at det gir god laering, i en læringsfilosofi hvor mening, nytte og deltakelse er de sentrale begreper (Skrøvset \& Tiller 2011). Studentene uttrykte det slik: «Opplevde at vi studenter var aktive hele dagen. Dette skaper engasjement og motivasjon for videre undervisning/teori i morgen (og nysgjerrighet). Bra med relevante eksempler».

«Motion» betyr bevegelse/aktivitet, og er en sentral del av ordet emosjon. Emosjoner er altså noe som beveger oss - hvis vi ikke «beveges» så skjer det ingen virkelig forandring (Mattson 
2009). At studentene var motiverte og engasjerte gjorde dem aktive og stimulerte til utvikling. En studentgruppe sa: «Vi ble også mer engasjert av denne læringsformen».

Den gode læring kjennetegnes av at den oppleves nyttig, både her og nå og i framtida (Skrøvset \& Tiller 2011). En av studentene bekreftet dette: «Dette er noe vi ser at vi kan ha god nytte av senere i livet».

Som pedagoger må vi hele tiden kjenne til hva som kreves av sykepleierne i dag (St.meld. 28 1999; St.meld. 47 2008). Vår oppgave som brobyggere ble derfor todelt: å stimulere studentene til en indre motivasjon som oppleves nyttig og å imøtekomme samfunnets krav til kompetanse. Motivasjon er knyttet til opplevelse av deltakelse og aktivitet, noe som ligger i aksjonslæringens idegrunnlag. Å være motivert skaper positive emosjoner (Antonsen 2009), slik en av studentgruppene sa: «Kjedelig tema som er blitt gjort til noe spennende og lærerikt pga. denne måten å jobbe på».

I aksjonslæring og aksjonsforskning står likeverdighet og deltakelse sentralt (Kalleberg 1992). En aksjon - i vårt tilfelle dialogkonferansen - er en handling med utgangspunkt i deltakernes virkelighet; deres opplevelse av å være studenter. Prosessen var deltakerstyrt og foregikk i et samarbeidende fellesskap (Greenwood \& Levin 2005; Tiller 2006). Dette illustreres med en av studentgruppenes uttalelse: «Moro å delta så mye i opplegget. Vi fikk bruke teori i praksis».

Studentenes ideer og forslag har ført til endringer blant annet i fagplan og rutiner. Disse endringene tok vi med videre til neste års studenter og slik startet en ny aksjonslæringsspiral. Enkelte studenter har som ferdige sykepleiere $\varnothing$ nsket å bruke verktøyene på egen arbeidsplass. De husker undervisningen og ser nytte av en slik prosess. I det at tidligere studenter har tatt kontakt mener vi å se et ønske om mer læring - men også en vedlikeholds- eller bærekraft (sustainability) i det de har erfart i undervisningen (Hargreaves \& Shirley 2009).

\section{Broen}

Ut fra vår problemstilling har vi forsøkt å vise hvordan dialogkonferanse i klasserommet som pedagogisk verktøy kan være med på å bygge en sterkere bro mellom teori og praksis. Våre 
funn viser at studentene i evalueringene spesielt trekker fram to områder: at de opplever engasjement og motivasjon ved å få være aktive og deltagende i egen læring, og at de ser nytte og overføringsverdi av de praktiske verktøy som inngår i prosessen.

Vår modell under illustrerer hvordan de ulike elementene i læringsprosessen henger sammen og danner en bro, for å synliggjøre hvordan gapet mellom teori og praksis kan bli mindre. (Figur 1)

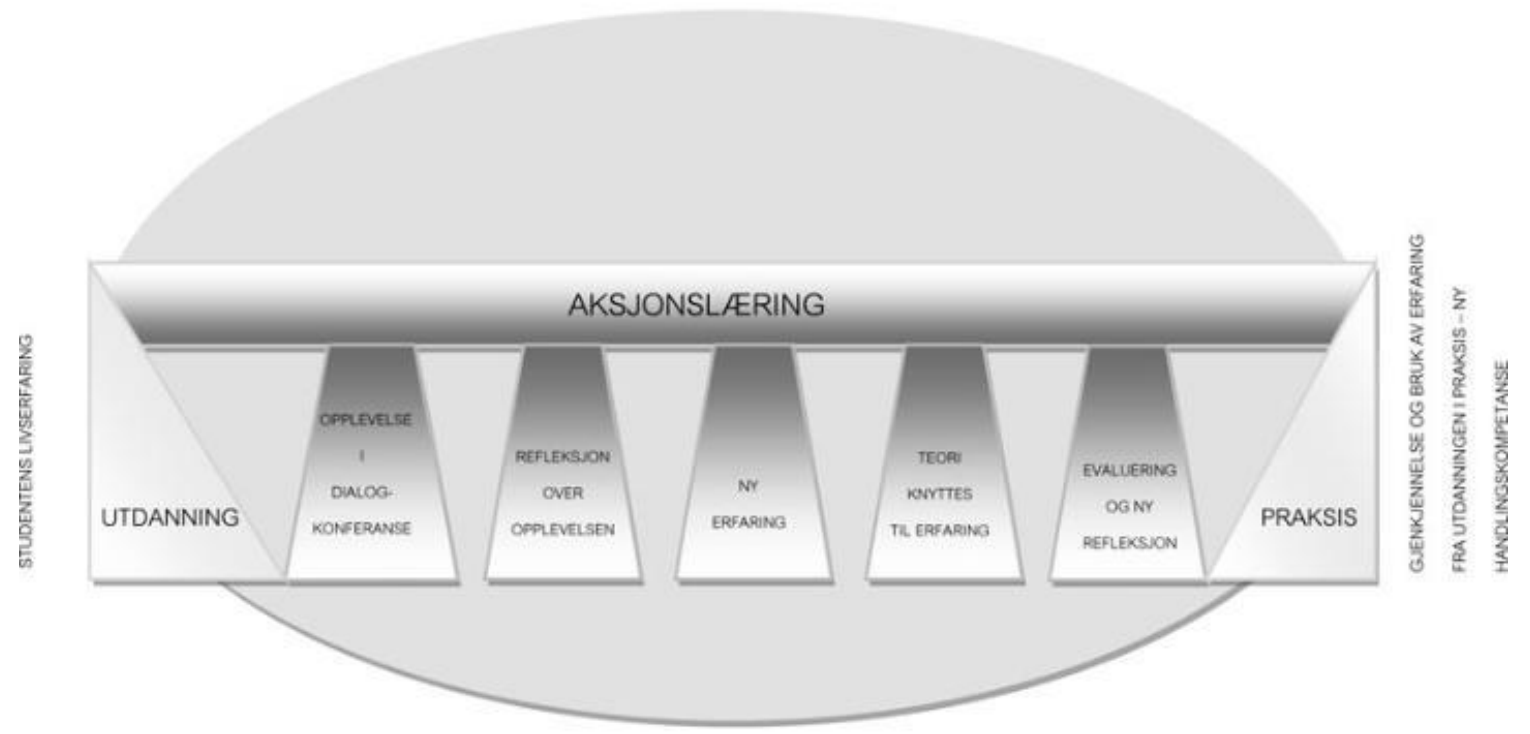

GAP MELLOM UTDANNING OG ARBEIDSLIV

Figur 1.: Broen

Huemer og Eriksen 2011

Veien over broen er den pedagogiske tilnærmingen som er aksjonslæring. Det som holder broen oppe er bropilarene som viser trinnene i læringstrappa og fasene i aksjonslæringsprosessen. Med handling, erfaring, refleksjon og knytting mot teori og ny handling (aksjon). Aksjonslæring har et fundament i den erfaringsbaserte læringen, og de har flere felles trekk, men også forskjeller. En tydelig forskjell er aksjonslæringenes aktive handling for å skape læring i den hensikt å forbedre praksis (Revans 1984; Bjørnsrud 2005).

Et sentralt fellestrekk er at både aksjonslæring og erfaringsbasert læring baserer seg på å gi mening for den lærende fordi den har en følelsemessig forankring. Den lærende blir grenseoverskridende og beveger seg fra det kjente til det ukjente, noe som kan være 
skremmende. Vi som lærere må derfor tilrettelegge for trygge læringsmiljø med rom for eksperimenter (Moxnes 2002; Brunstad 2009; Jakhelln, Leming \& Tiller 2009).

På den andre siden av «gapet» under broen finner vi arbeidshverdagen hvor kunnskapen omsettes i praksis. Moxnes (2002) sier at nå gjenstår det å anvende kunnskapen i nye analoge situasjoner. Den lærende vil kunne gjenkjenne elementer fra teori og erfaring i skolen og handle ut fra dette.

Vi må leve som vi lærer - ellers kan mennesker i organisasjonen føle seg fremmedgjort og emosjoner for utvikling forhindres (Starrin 2009).

\section{Ringer i vann}

Vårt prosjekt ble startet av oss som nye lærere på Høgskolen, i den hensikt å forbedre læringsutbyttet til studentene innen endringskompetanse. Vi måtte tilpasse det til rammene for den tildelte undervisningstid for temaet. Dette var og er en utfordring, da systemene for tildeling av undervisningsressurs ikke alltid fanger opp nye behov ved bruk av endrede arbeidsformer i undervisningen. De senere år er tolærersystemet oftere anvendt innen noen tema, og flere faglærere har tatt inn dialogseminar/konferanse som en metode $\mathrm{i}$ undervisningen. Sånn sett kan man si at vårt prosjekt har inspirert andre faglærere ved instituttet, og at studentenes læringsutbytte har kommet mer i fokus. Imidlertid krever $\varnothing \mathrm{kt}$ bruk av aksjonslæring som læringsform og dialogseminar som læringsverktøy, en kritisk gjennomgang av dagens rammebetingelser for undervisning i et mer overordnet og helhetlig perspektiv relatert til fagplanens intensjoner, lærerressurser og materielle strukturer. Det krever også at det verdsettende perspektiv får $\emptyset \mathrm{kt}$ fokus i lærerkollegiet. 


\section{Litteratur}

Adizes, Ichak (1991). Endring kan mestres. Oslo: Universitetsforlaget.

Alvsvåg, Herdis \& Oddvar Førland (2004). Nyutdannede sykepleiere sitt syn på

sykepleierutdanningen i lys av erfaringer som yrkesaktive (FoU-rapport nr. 1/04). Oslo:

Diakonissehjemmets høgskole.

Antonsen, Yngve (2009). Aktør- og offerhistorier som læringsverktøy. I Rakel Jakhelln, Tove Leming \& Tom Tiller (red.). Emosjoner i forskning og laring. Troms $\varnothing$ : Eureka forlag.

Bjørndal, Bjarne \& Sigmund Lieberg (1978). Nye veier i didaktikken. Oslo: Aschehoug.

Bjørnsrud, Halvor (2005). Rom for aksjonslaring Om tilpasset opplaering, inkludering og laereplanarbeid. Gyldendal Akademisk.

Brunstad, Paul O. (2009). Klokt lederskap mellom dyder og dødssynder. Oslo: Gyldendal Norsk Forlag AS.

Eriksen, Liss T. (2007). Det handler jo om oss: hvordan lede og tilrettelegge en organisasjonsutviklingsprosess i eget arbeidsmiljø? Lillestrøm: Høgskolen i Akershus.

Espeland, Oddny \& Valbjørg Indrehus (2003). Evaluation of Students' Satisfaction with Nursing Education in Norway. Journal of Advanced Nursing 42, 3, 226-236.

Etzioni, Amitai (1967). Mixed-Scanning: A «Third» Approach to Decision-Making. Public Administration Review 27, 5, 385-392.

Greenwood, Davydd J. \& Morten Levin (2005). Reform of the Social Sciences and of Universities through Action Research. I Norman Denzin \& Yvonna Lincoln (red.). The Sage Handbook of qualitative research. Thousand Oaks: Sage.

Gustavsen, Bjørn (1996). Development and Social Sciences. I Stephen Toulmin \& Bjørn Gustavsen (red.). Beyond Theory. Changing Organizations through Participations.

Amsterdam: John Benjamin's Publishing Company.

Hargreaves, Andy \& Dennis Shirley (2009). The Fourth Way - The Inspiring Future for Educational Change. Thousand Oaks, CA: Corwin Press.

Havn, Vidar \& Camilla Vedi (1997). På dypt vann: om nyutdannede sykepleieres kompetanse i møtet med en somatisk sengepost. Trondheim: SINTEF IFIM.

Jakhelln, Rakel, Tove Leming \& Tom Tiller (2009). Emosjoner i forskning og læring. I Rakel Jakhelln, Tove Leming \& Tom Tiller (red.). Emosjoner i forskning og laring. Troms $\varnothing$ :

Eureka forlag.

Jacobsen, Bo (2001). Voksenundervisning og livserfaring. København: Christian Ejlers forlag. 
Jordell, Karl Ø. (1986). Fra pult til kateter. Om sosialisering til laereryrket. Tromsø: Universitetet i Tromsø.

Kalleberg, Ragnvald (1992). Konstruktiv samfunnsvitenskap. En fagteoretisk plassering av aksjonsforskning (ISO Rapport nr. 24). Oslo: Universitetet i Oslo.

Kirke-, utdannings- og forskningsdepartementet (1999). Tiltak for å styrke sykepleierutdanningen. Oslo.

Knowles, Malcolm S. (1970). The Modern Practice of Adult Education: Andragogy Versus Pedagogy. New York: Cambridge Books.

Kunnskapsdepartementet (2005). Lov om universiteter og høgskoler. Oslo.

Kunnskapsdepartementet (2008). Forskrift til rammeplan for sykepleierutdanning. Oslo.

Levin, Morten \& Roger Klev (2002). Forandring som praksis: laring og utvikling $i$ organisasjoner. Bergen: Fagbokforlaget.

Løchen, Yngvar (1973). Aksjonsforskningen. I Vilhelm Aubert (red.). Sosiologien $i$ samfunnet. Oslo: Universitetsforlaget.

Maben, Jill, Sue Latter \& Jill Macleod Clark (2006). The Theory-Practice Gap: Impact of Professional Bureaucratic Work Conflict on Newly-Qualified Nurses. Journal of Advanced Nursing 55, 4, 465-477.

Mattson, Matts (2009). Emotionsforskning och aktionslärande - avslutande reflektioner. I Rakel Jakhelln, Tove Leming \& Tom Tiller (red.). Emosjoner i forskning og laering. Troms $\varnothing$ : Eureka forlag.

Moxnes, Paul (2002). Laring og ressursutvikling i arbeidsmiljøet-pedagogisk arbeidspsykologi i forskning og praksis. Oslo: Forlaget Paul Moxness.

Orvik, Arne (2002). Organisatorisk kompetanse motvirker realitetssjokket. Sykepleien 90(8), 42-46. DOI: 10.4220/sykepleiens.2002.0023

Paulgaard, Gry (1997). Feltarbeid i egen kultur: innenfra, utenfra eller begge deler? I Erik Fossåskaret, Otto Laurits Fuglestad \& Tor Halfdan Aase (red.). Metodisk feltarbeid: produksjon og tolkning av kvalitative data. Oslo: Universitetsforlaget.

Patton, Michael Q. (2002). Qualitative Research \& Evaluation Methods. Thousand Oaks, Calif.: Sage Publications.

Pålshaugen, Øyvind (2002). Dialogkonferanser som metode i bedriftsutvikling. I Morten Levin \& Roger Klev (red.). Forandring i praksis - laring og utvikling i organisasjoner. Bergen: Fagbokforlaget.

Reason, Peter \& Hilary Bradbury (2001). Handbook of Action Research. Participate Inquiry \& Practice. London: SAGE. 
Revans, Reginald. W. (1984). Aksjonslaeringens ABC. Oslo: Bedriftsøkonomens Forlag.

Ricœur, Paul (2001). Hva er en tekst? Å forstå og forklare. I Sissel Lægreid \& Torgeir Skorgen (red.). Hermeneutisk lesebok. Oslo: Spartacus.

Ruyter, Knut W, Reidun Førde \& Jan H. Solbakk (2007). Medisinsk og helsefaglig etikk. Oslo: Gyldendal Akademisk.

Skrøvset, Siw \& Tom Tiller (2011). Verdsettende ledelse. Kristiansand: Høgskoleforlaget.

Smeby, Jens-Christian \& André Vågan (2007). Fra utdanning til arbeid. I Herdis Alvsvåg \& Oddvar Førland (red.). Engasjement og laring - fagkritiske perspektiver på sykepleie. Oslo: Akribe.

Starrin, Bengt (2009). Det våres for emosjoner i samfunnsvitenskapen. I Rakel Jakhelln, Tove Leming \& Tom Tiller (red.). Emosjoner i forskning og laring. Troms $\varnothing$ : Eureka forlag.

St.meld. 28 (1999). Innhald og kvalitet i omsorgstenestene: omsorg 2000. Sosial- og helsedepartementet.

St.meld. 47 (2008-2009). Samhandlingsreformen: Rett behandling - på rett sted - til rett tid. Helse- og omsorgsdepartementet.

Stronach, Ian mfl. (2002). Towards an Uncertain Politics of Professionalism: Teacher and Nurse Identities in Flux. Journal of Education Policy 27, 2, 109-138.

Tiller, Tom (1986). Den tenkende skolen. Om organisasjonsutvikling og aksjonslaring på skolens egne premisser. Oslo: Universitetsforlaget.

Tiller, Tom (1998) Det didaktiske møte. Vejle: Kroghs Forlag AS.

Tiller, Tom (2004). Forpliktende forskningsfantasi. I Tom Tiller (red.). Aksjonsforskning $i$ skole og utdanning. Kristiansand: Høgskoleforlaget.

Tiller, Tom (2006). Aksjonslaering - forskende partnerskap i skolen: motoren i det nye laeringsløftet. Kristiansand: Høgskoleforlaget. 